\title{
Fashioning clothing with and for mature women: a small- scale sustainable design business model
}

\begin{tabular}{|r|l|}
\hline Journal: & Management Decision \\
\hline Manuscript ID & MD-12-2016-0942.R3 \\
\hline Manuscript Type: & Original Article \\
\hline Keywords: & $\begin{array}{l}\text { Mature fashion consumer, Womenswear, Sustainable fashion, Action } \\
\text { research, Business model }\end{array}$ \\
\hline \multicolumn{2}{|c}{} \\
\hline
\end{tabular}

\section{SCHOLARONE ${ }^{\text {w }}$ \\ Manuscripts}




\title{
Fashioning clothing with and for mature women: a small-scale sustainable design business
} model

\begin{abstract}
Purpose - An ageing population in the developed world has become a significant topic in the contemporary research agenda. The aim of this paper is to report on the development of a new small-scale business model based on facilitating in-depth understanding and responding to mature female consumers' needs and expectations towards fashionable clothing.

Design/ methodology - Two complementary approaches are used: Interpretative Phenomenological Analysis (IPA) allows the researchers to employ the life-course perspective and to develop in-depth understanding of individuals' present experiences in relation to their past. Action Research offers the possibility to develop participatory, co-design processes based on collective creativity and mutual knowledge exchange between the stakeholders.

Findings - The research finds a strong interest in fashionable clothing by women, irrespective of their age. The action based co-design process involving collaborative encounters with mature consumers creates a dynamic capability for alternative fashion design methodologies. This approach can contribute to a small-scale fashion business model for the mature women's fashion market.

Practical implications - The women in the study stress the need for a more inclusive design process and expressed a willingness to buy from a brand/ retailer who would offer them such a collaborative opportunity. There are practical implications for how a more flexible sizing approach to the design of fashion for older women could be implemented.

Originality/value -This research makes a contribution to practice-based design solutions for mature women and a new inclusive business model based on emotional durability. The innovative methodological approach contributes to the field of ethical and sustainable fashion design.
\end{abstract}

Keywords: Mature fashion consumer, womenswear, sustainable fashion, action research, business model.

Paper type: Empirical paper 


\section{Introduction}

An ageing global population has attracted considerable research interest in the fields of social and cultural gerontology, with a focus on the phenomenon of growing old and the effects on individuals and society as a whole (Gilleard and Higgs, 2000; Gilleard and Higgs, 2014). In post-industrial economies, improvements in employment, healthcare, sports and leisure have affected both the biological and sociocultural conditions of ageing, producing new opportunities and challenges for marketers (Mintel, 2015). For the fashion industry, which focuses mainly on youth markets, it has become increasingly important to understand and cater for the needs of mature individuals. While this has led to an increase in studies of the relationship between fashion and ageing (Twigg, 2007; 2009; 2013; Hurd Clarke et al., 2009; Tiggemann and Lacey 2009, Peters et al. 2011, Holmund et al., 2010) there has been limited research into business models to develop this market (Iltanen and Topo, 2007; McCann, 2008; McCann and Bryson, 2014; Townsend et al.,2017). The fast fashion model has succeeded by exploiting supply chain efficiencies to respond to rapidly changing demands from younger consumers. However, mature consumers have different fashion style and fit needs. In meeting these, a slow, fashion business model that uses innovative design practices can be a significant strategic resource. To date, the main change factors in sustainable fashion design have focused on ethical sourcing and production issues with business models continuing to be linked to large volumes of sales and production (Niinimaki and Hassi 2011) with limited engagement with consumers in value creation through the design process. The aim of this research is to address this gap in knowledge through the co-design of fashion clothing for mature women. The objectives are first, to locate the incidence and growth of small, sustainable business models in the fashion industry, second to assess the organisation and outcomes of the action-based co-design methodology with a participating group, and third to develop a fashion business model suitable for SME's targeting the mature women's market. Through its focus on participative design, the research will develop Teece's (2010) value creation approach to the business model, to achieve sustainable competitive advantage.

\section{Literature review}

The use of the business model as a management concept gained prominence with the growth of the Internet and e-commerce in the 1990s, and can be defined as the 'logic of the firm, the way it operates and how it creates value for its stakeholders' (Casadesus-Masanell and Ricart, 2010, p.195). It often demonstrates innovative approaches (Cavalcante et al. 2011, Chesbrough, 2010; Markides 2015) and describes the design or architecture of the value capturing mechanisms of a business (Teece, 2010; DaSilva and Trkman, 2014). The dominant theoretical frameworks of business model research are centred on resource-based perspectives of the firm, competitive strategy, networks and value chains (Potishuk, 
2013; Mateu and March-Chorda, 2016). The value they create can span firms' and industries' boundaries (Amit and Zott (2001) to include constellations of stakeholders that co-construct firms within their wider ecosystems (Chandrasekara and Harrison, 2013). The prevailing fashion business model, fast fashion, reflects a networked perspective through the configuration of complex supply chains (Jin et al., 2012), and the creation of value from sourcing clothing and accessory designs at affordable prices that are frequently changed to maintain their originality and style (Sheridan et al., 2006; Kent, 2017).

By contrast, slow fashion provides a framework for an alternative business model that creates value through small-scale production, traditional craft techniques, local materials and markets (Braungart et al., 2007; Fletcher, 2016; Fletcher and Grose, 2012). Their design focuses on customization and longevity (Gwilt and Rissanen, 2011; Twigger-Holroyd, 2010; Minney 2016). In the value creation process, it enables a richer interaction and stronger bonds between designers, producers, garments, and users and includes the consumer in the supply chain as co-producer (Fletcher 2007). Teece's (2010) approach to business modelling proposes targeting specific markets and a value proposition of new offerings which can be achieved through innovative designs to the consumer (Child, et al. 2017).

Women's clothing presents a significant design challenge is its size and fit to the body. Few fast fashion garments have a good fit while also being flexible enough for changes in user's weight and body shape (Laitala, Boks and Grimstad Klepp 2015). And while the fast fashion business model is targeted at younger consumer, it tends to neglect older women over the age of 55 (Mintel, 2012) and for these women, specialist outlets such as boutique retailers, have virtually disappeared (Fogg, 2003).

Nevertheless, more than $60 \%$ of British women feel that the over 50 s generation is offered limited shape and style options by UK retailers (Smithers, 2014, online). Moreover, these consumers are shown to have a continuing and active interest in fashionable clothing (Twigg, 2013). Given the growth and spending power of the older women's market but also the scalability of slow fashion (Pal and Gander, 2018) it is important for SME businesses to identify new ways of appealing to and engaging with this demographic (Bassett, 2017, online).

Fast fashion, sustainability and innovation were one of the themes of the End of Fashion (2016) conference, Massey University, Wellington, which challenged the dramatic shifts that have occurred in fashion. During a Designer Forum event, a panel of experts comprising fashion theorists and practitioners discussed the need for the Industry to adopt more personal, small-scale models to meet the evolving design needs of mature customers. Such models still exist in New Zealand, as confirmed by Liz Findlay from Zambezi and Margi Robertson $N^{*}{ }^{*}$, two independent brands who have sustained a close relationship with their customers since the 1970s by adapting their in-house collections accordingly. Similarly, the Everybody and Everything as Material: Beyond fashion design methods (2017) conference, 
University of Boras, Sweden, facilitated critical reflection on the need for more inclusive methodologies. Boras alumni and co-founder of Swedish brand Atacac, Dr Rickard Lindqvist, has introduced a 'kinetic' garment design and construction method to accommodate a wide range of body shapes and encourages customers to download free patterns to create their own versions (Atacac, 2017). The company has also reversed the orthodox 'high to low' product pricing approach, by creating limited editions that become more expensive and desirable as they sell-out. There is evidence of a growing number of UK independent companies exploring more inclusive design, such as THE-BIAS-CUT, who are developing versatile products that challenge fashion ageism (Bassett, 2017, online).

These businesses demonstrate Fletcher's (2012) possibilities of transforming fashion design through participatory, co-design principles and practices, using small design businesses as effective agents of change (Millspaugh and Kent, 2016). Value is achieved through sustainable design and garment shaping, sourcing, making and distribution (Fletcher, 2016; Gwilt and Rissanen, 2011; Rissanen and McQuillan, 2015; Townsend and Mills, 2013). However less well known are the needs and expectations of mature female consumers over the age of 55 and how they can contribute to a new sustainable smallscale business model oriented at UK consumers (Townsend et al., 2016). The research questions that address this gap are first, how do mature women select and wear contemporary high street fashion? Second, how does an action-based co-design approach with mature women contribute to the development of the fashion clothing market? And finally, what are the key characteristics of a fashion business model targeted at mature women?

\section{Methodology}

The research was designed around the 'Emotional Fit' project (Sadkowska et al., 2015; Townsend et al., 2017) which utilised older women's expertise, knowledge and understanding of garment longevity to develop a sustainable fashion methodology based on "product attachment and emotionally satisfying design" (Niimimaki, 2011: 282) The analysis of a series of research workshops and in-depth interviews with the participants informed the development of the methodology and business model. This led to an assessment of the model to accommodate mature female consumers physical and psychological needs alongside aesthetic expectations, existing practices of clothing consumption and their implications for sustainability.

The methodology combined two approaches, Interpretative Phenomenological Analysis (IPA), typically used in healthcare (Smith, 1996; Smith et al., 2009) and Action Research. IPA is a hermeneutic approach to research; its main concern being the detailed examination of how individuals understand and interpret their personal life experiences. Researchers must recognise their own views as well as 
"interactions between researcher and participant" enabling them to develop an empathetic, yet questioning and interrogative research attitude (Finlay, 2011, p. 140). Significantly, IPA does not require researchers to test theoretically-derived hypotheses (Langdridge, 2007), but supports the gradual exploration an issue. The participants life-long interest in fashion allowed the researchers to employ IPA as a method for considering their life-course perspectives, while developing in-depth understanding of their current experiences of fashion, in relation to their past.

IPA is complemented by Action Research in which a spiral of action and reflection cycles are central to developing, implementing, and evaluating action or intervention plans to improve practice (Ivankova, 2015). As an enquiry strategy that integrates experience, action and reflection (Reason, 1994) it fosters collaboration among its participants to advance both knowledge and practical problem solving (Mcgrath and O'Toole, 2012). Practical or iterative Action Research aspires to change, but also informs the practical decision making of practitioners to identify problems, determine solutions and evaluate outcomes (Kemmis, 2006: 95 in Mcgrath and O'Toole, 2012). This approach leads to a better understanding of the underlying problems and their causes with the researcher and the practitioners jointly identifying possible interventions (Holter and Schwartz-Barcott, 1993, p.301). Further it allows for a more flexible approach in design and delivery (Grundy, 1982) that accommodate co-design practices (Manzini, 2015; Sanders and Stappers, 2012) that create value (Piller et al., 2005: online).

At the core of co-design is the integration of the consumers into the "value creation by defining, configuring, matching, or modifying their individual solution" (Piller et al., 2005: online). Consumers become active co-designers rather than advisors or co-producers, expressing their product preferences and expectations, often via physical interaction with objects and materials (Wu, 2010; Ulrich et al, 2003). McCann (2016, p. 253) evaluates apparel co-design as having the potential "to promote a more responsible, value-added, slower product development, involving end-users at every stage." Co-design methods have also been applied to new product and service development in management research (Durugbo, 2014; Li and Qiu, 2006) through the use of design tools, methods and techniques to build relationships with stakeholders and coordinate design efforts (da Silveira, 2011). In this project, codesign involved the collaborative exchange of the participants and researchers' knowledge, skills and understanding of designing, making and wearing clothing to create a new "shared value" (Manzini 2015) of how fashion is designed and produced for older women.

The researchers recruited forty-five participants, comprised of a self-formed group that had initially contacted the university's fashion department to enquire about design education in fashion for mature consumers, thereby forming an available convenience sample for the research team to work with (Bryman, 2015). Originally formed in 2012 through a shared interest in fashion, the group grew by the 
start of the project in 2015 and comprised British women over 55 years old, most of whom were retired, or semi-retired from professional occupations and live in and around Nottingham, UK.

The participants were all interested in ethical sourcing and sustainable consumption, distancing themselves from fast fashion, and its contribution to over-consumption and disposability. Instead, they valued style, versatility, longevity, and high quality textiles and clothing, reflecting some of this demographic group's main priorities (Mintel, 2016). Many of the participants also had a lifelong interest in dressmaking, which they had first learnt through needlework at school, then practiced via home dressmaking as young women in the 1960s and 1970s (Goode, 2016). Most of the women had continued to use these skills, often in response to finding "mass-produced clothing an uneasy fit" (Aldrich 2004: 4). Their active interest in fashion and clothing, combined with their experiential knowledge and skills of making and wearing fashion, enabled the co-designing dimension of methodology. The collaborative enquiry was augmented by the professional knowledge and expertise of the action research practitioners, whose design objectives became focused on their potential future users (Sanders and Stappers 2008). The research team was comprised of three designers with experience in industry and practice-led research in textile and sustainable fashion design (Townsend 2004; Townsend and Mills, 2013) textile design, fashion and aging (Sadkowska et al., 2017) fashion knitwear design and creative pattern cutting (Sissons, 2010).

The research was conducted in two phases between May 2015 and April 2016: Phase One: Gathering experiential knowledge and design data, incorporating two diagnostic workshops and interviews and Phase Two: Knowledge exchange and testing the potential model, incorporating two creative workshops.

\section{Phase One: Gathering experiential knowledge and design data}

During Phase One, the aim of the workshops was to take measurements, explore issues of garment sizing and fit and aesthetic preferences supporting product attachment in fashion to inform a more sustainable fashion model (Niinimaki and Hassi, 2011). Workshop 1, held in two session in May 2015, lasting three hours, and attended by 21 (10/11) participants. Consistent with the principles of IPA, It was focused entirely on developing an in-depth understanding of the participants' past and present experiences of fashion and clothing, its meaning to them and how they make sense of it (Townsend et al 2017: 240). The session incorporated a 'show and tell' exercise of participants most and least favorite garments (fig. 1); taking detailed body measurements of each participant (fig. 2), a group discussion of clothing preferences using fashion and lifestyle magazines as stimuli, including Vogue, Marie Claire and Saga. These fashion conversations enabled the researchers to develop a rapport with the participants, 


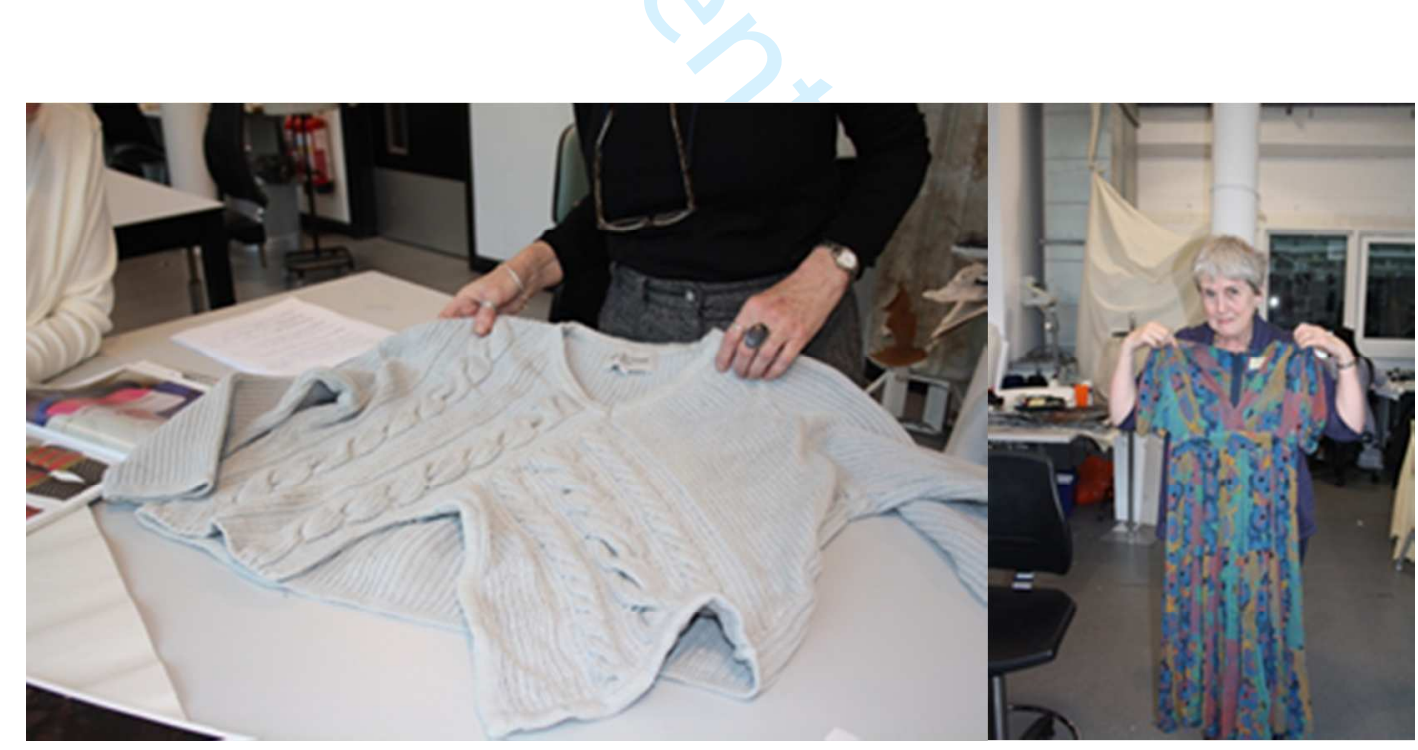

Figure 2a-b. Workshop 1: Recording a favorite garment; Show and tell.

In order to build on the qualitative data accrued in Workshop 1, a series of in-depth semistructured interviews were undertaken with five participants in June and July 2015. Following the requirements of IPA, the selection process was based on the participants' suitability in terms of their

while establishing insights into individual aesthetic preferences, alongside technical details of existing clothing: silhouette, style, cut, length; colour, pattern, texture. The resulting qualitative data consisting of personal disclosures of attitudes, opinions and intentions towards fashion (Wilkinson, 2003) was supplemented with quantitative measurements.

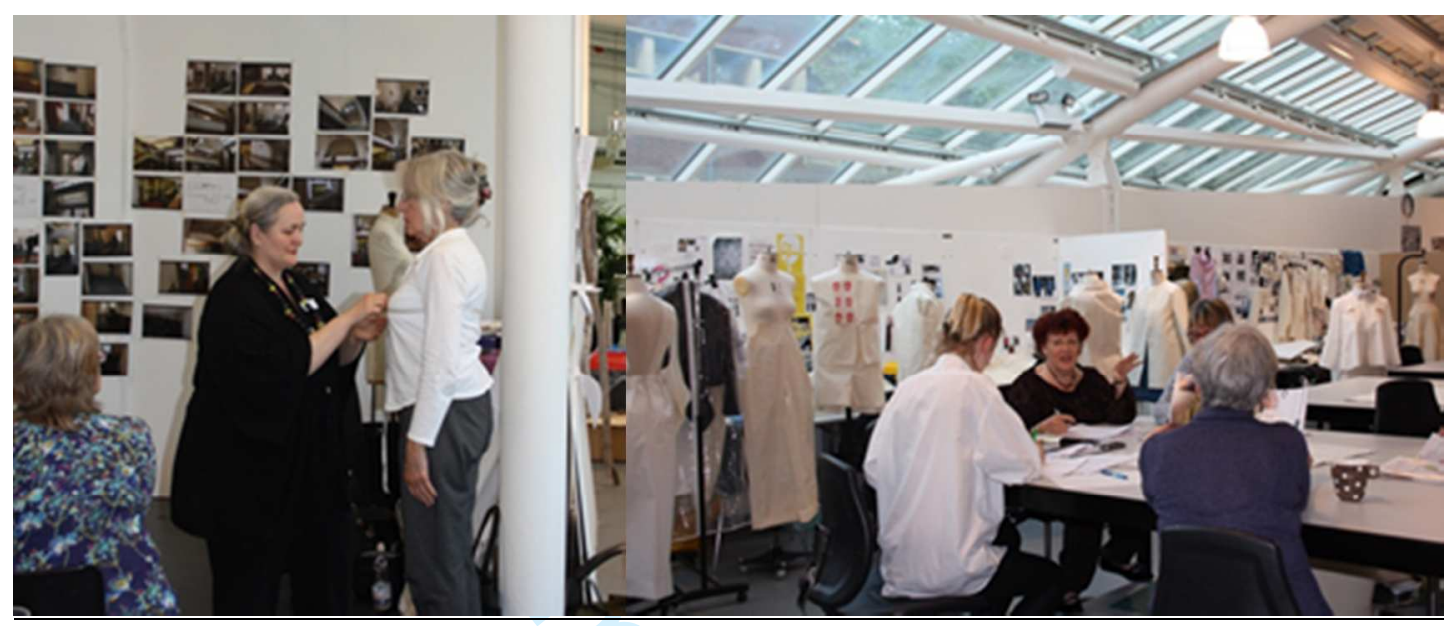

Figure 1a-b. Workshop 1: Taking body measurements; Small group discussion. 
experiences, expertise, interests and active pursuit of sustainable clothing practices, to allow for different, yet conceptually unified themes to emerge (Smith et al, 2009). The age range of the interviewees was 6467; one was semi-retired and four were retired. The questions addressed favorite/ least favorite fashion items; best/ worst fashion experiences; sources and methods of purchasing/ acquiring clothing; everyday clothing practices, including selecting, styling, wearing, caring for and disposing of clothing, fashion problems/ issues faced and experienced and, finally, their recommendations for how to improve their experiences. The interviews were undertaken in June and July 2015 at Nottingham Trent University, lasted 60-80 minutes and were digitally recorded and transcribed verbatim with consent from each participant.

Workshop 2 was conducted in June 2015 and was attended by 21 participants, who together with the researchers explored the exchange of ideas based on the group's "diffuse and expert knowledge" (Manzini 2015, p.37). Firstly, participants were introduced to the principles of geometric pattern cutting, an approach selected to accommodate multiple body shapes and preferences emerging from the study, while minimizing waste (Rissanen and McQuillan, 2015). Secondly, returning participants tried on the calico bodices (figure 3), constructed in relation to their body measurements (acquired in Workshop 1) cross-referenced with those from UK British Standard sizing charts (British Standard Institute, 2001). The development of 'live' blocks was the first stage of developing prototypes in line with the women's individual shape and style (Aldrich 2004, p.4). New participants were measured, their garments and preferences recorded to build on the data from Workshop 1.

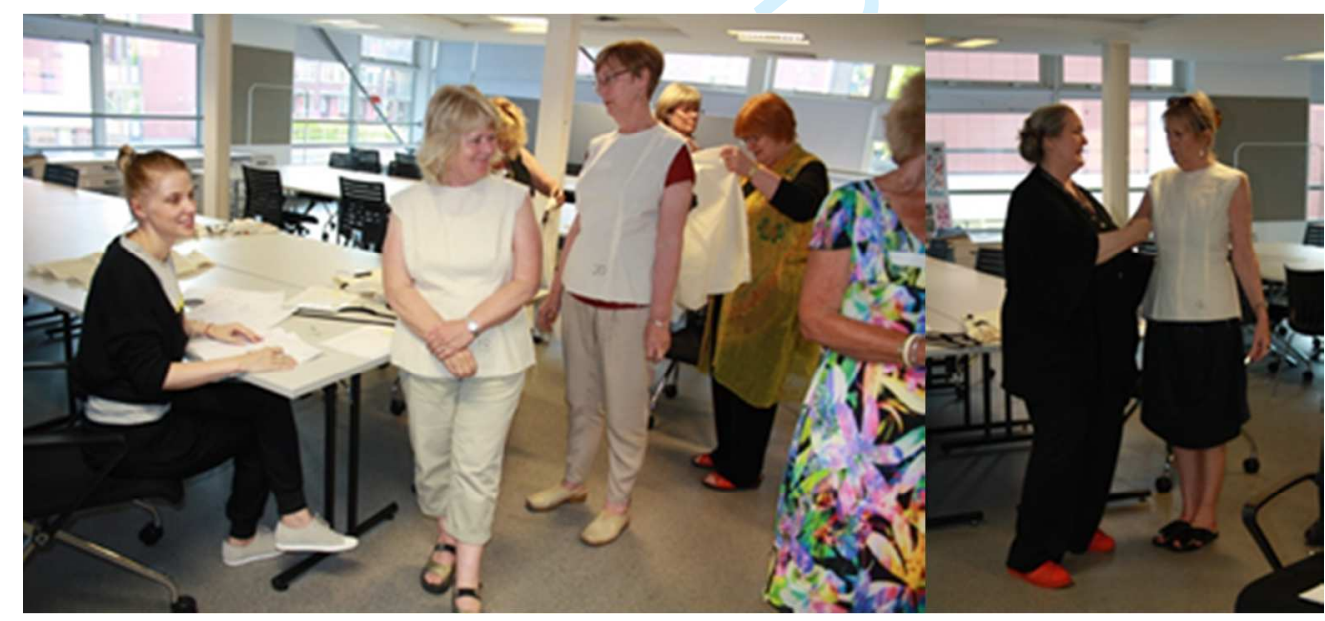

Figure 3. Workshop 2: the participants trying on the bespoke calico bodices, produced to their individual measurements and according to UK sizing charts (British Standards Institute, 2001). 


\begin{tabular}{|c|c|c|}
\hline Superordinate (master) theme & \multicolumn{2}{|c|}{ Subordinate themes (variations) } \\
\hline Fashion awareness & $\begin{array}{c}\text { limitations of the current } \\
\text { market offer }\end{array}$ & $\begin{array}{c}\text { filtering contemporary trends } \\
\text { through individual needs and } \\
\text { expectations }\end{array}$ \\
\hline Sense of belonging & $\begin{array}{c}\text { style and longevity (personal } \\
\text { likes and dislikes) }\end{array}$ & $\begin{array}{c}\text { constant negotiating between } \\
\text { individual preferences, and } \\
\text { shared generational and socio- } \\
\text { cultural connections }\end{array}$ \\
\hline Bodily changes & $\begin{array}{c}\text { issues with sizing and fit/ } \\
\text { changing physicality and its } \\
\text { impact on embodied } \\
\text { experiences }\end{array}$ & $\begin{array}{c}\text { emotional memory; past body as } \\
\text { a point of reference }\end{array}$ \\
\hline Personal trajectories & $\begin{array}{c}\text { the significance of the individual } \\
\text { life courses }\end{array}$ & $\begin{array}{c}\text { fashion and textile experiences } \\
\text { as touchstones }\end{array}$ \\
\hline Textiles as a catalyst & $\begin{array}{c}\text { textiles providing a 'material } \\
\text { gestalt' underpinning the } \\
\text { participants' fashion identities }\end{array}$ & $\begin{array}{c}\text { surface pattern as embodied } \\
\text { narrative and emotional } \\
\text { expression }\end{array}$ \\
\hline
\end{tabular}

\section{Analysis of Interview Data}

Analysis of the interviews was completed in December 2015, to inform Workshops 3 and 4. The data analysis used the procedure typical to IPA (Smith et al, 2009; Finlay, 2011), i.e. a process by which interview transcripts were read and re-read several times, with note taking to generate an initial set of emergent themes; at the initial stage of analysis 'fashion' functioned as a broad analytic category. This was followed by a stage of developing the identified emergent themes and searching for connections across them; here the focus was on abstracting and integrating similar thematic entities to reduce the overall number of themes. These steps were repeated with all five transcribed interviews, implementing the steps of looking for patterns across all five cases; followed by the final stage of developing the interpretations to a deeper level. This systematic process of IPA data analysis resulted in a set of superordinate (master) themes, and corresponding set of subordinate themes (variations). These were subsequently grouped together and collapsed into the five superordinate themes, with further two subthemes each (tab. 1). Of relevance to this article is the selection of master themes including ' Fashion awareness', "Sense of belonging" and "Bodily changes". 
It was through the interviews that the participants' conceptual preferences relating to the style and functionality of garments emerged. The main desirable categories were: transformability and adaptability to facilitate contrasting activities; appreciation of natural fibres and sustainably-produced fashion and textiles; tertiary colour palettes and prints; and, as a core category, product longevity. For example, Participant 2 explained her idea for a durable collection by having a wardrobe of "very stylish clothes that could be worn across the seasons but with different sorts of layers or tops." The same participant commented on the importance of a "long-lasting emotional connection" with her clothing, resulting in her rejection of "really cheap", mass-produced garments, which are not designed to last and a preference for: "clothes that I love to have with me [and] that I look into the wardrobe and think, oh, I love that, even if I'm not wearing it."

Participant 1 identified the gap in the market for stylish, ethically produced clothing, by discussing how difficult she found it to find sustainable solutions that were "easy to care for, functional and aesthetically pleasing." Finally, Participant 3 offered insights into the complex relationship between fashion, ageing and sustainable clothing consumption by confirming that for her it presented all sorts of "dilemmas" in relation to "ethical issues, disposability, fast turnaround times" and that it was predominantly "a young person's game." Overall, the data reinforced a need for creating emotionally durable design (Chapman 2015) that catalyze "product attachment" as described by Schifferstein and Zwartkruis-Pilgrim (2008).

\section{Findings: Themes emerging from Phase One}

Analysis of Phase One of the research generated three overarching themes: 1) 'limitations of the current market offer', linked to 2) 'sizing and fit', and 3) 'style and longevity'. Theme 1 was common to all the participants, who shared a strong sense of dissatisfaction and disconnection with contemporary fashion. This was experienced differently by individuals; some felt frustrated with the lack of clothes that suited their aging bodies, others stressed the dearth of creatively cut, aesthetic clothing, with choices limited to generic shapes and on-trend or dull colourways. Most raised ethical sourcing and manufacturing issues as a concern and all believed that most fashion retailers were not adequately engaging with, or catering for their needs triggering feelings of exclusion.

Analysis of theme 2) sizing and fit, found that the bespoke calico bodices, constructed to each participant's measurements and labeled in UK sizes 10 - 24 (British Standard Institute 2001) were generally one or two sizes larger than their purchased or perceived size. This raised issues of self-esteem amongst the participants, until everyone realized that the disparity was common to all. This identified potential psychological effects of garment labeling, how it can affect a wearer's perceptions of self and body image, enhancing or diminishing feelings of wellbeing and potential emotional attachment to a 
garment. This evidence supports the need for new fashion business models to move away from standardized sizing towards alternative nomenclature and fewer definitive sizes within a range.

Third, in terms of style and longevity, the participants responded positively to geometric silhouettes to accommodate different body shapes and flexible styling while simultaneously reducing fabric waste (Townsend et al., 2017: 247). This design approach triggered personal connections with the oversized aesthetics of the 1970s and 80s that they enjoyed wearing in the past by facilitating "elegance, comfort and openness" (Van Essche, cited in Aakko, 2016: 187). They were also intrigued by the transformative shaping potential of engineering prints with squares (including triangles), rectangles and circles (Townsend 2004). The themes and findings directly informed the co-designing process in Phase Two and the resulting "in between" fashion (Aakko 2016) prototypes developed. In conversation, a number of women reflected that having the opportunity to discuss these issues helped to validate their concerns and ideas. The dialogic process established a rapport between the participants and the researchers, which was critical for the project's co-creative rationale.

\section{Phase Two: Knowledge exchange and testing the potential model}

The second phase of research culminated in two co-designing workshops ( 3 and 4), which were similarly structured and conducted in March and April 2016. Following IPA's commitment to idiographic, inductive and interrogative analysis the aim of the workshops was to elicit the 'means' of how fashion actors are engaged in particular forms of interaction, and the eventual 'ends' of experiential value that are co-created (Smith et al 2009). Consequently, participants worked collaboratively in each workshop with the researchers to develop a capsule collection, which effectively responded to the practical, emotional and ethical issues raised. This involved hands-on practical exercises, where toiles and printed textile swatches were tried on, manipulated and selected by the participants, facilitating the design development process (figs 4 and 5).

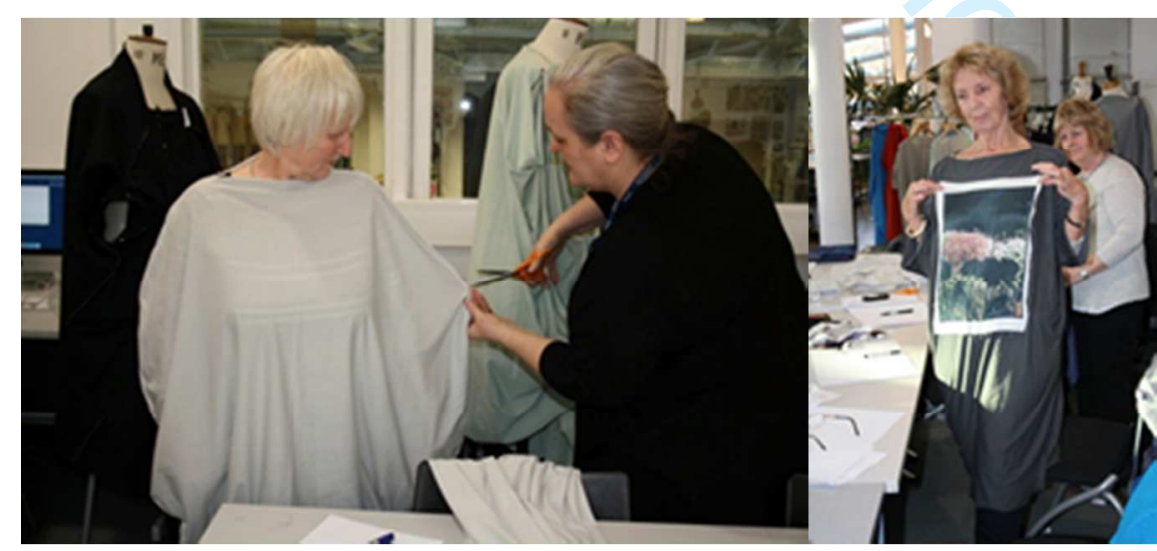

Figure 4. Workshop 3: A researcher adapting a toile; trying on toiles and selecting prints. 
Figure 5. Workshop 4: Participants trying on the Triangle Jacket and Rectangle Dress toiles and selecting print designs.

Phase 2 of the project culminated in the production of 30 garment prototypes (between June 2016 and April 2017) in contrasting textiles, including: Rectangle Dress 1, Triangle Dress, Jacket (fig. 6), coordinating tops, tunics and trousers in Small (8-12), Medium (12-16) and Ample (16-20). Rectangle Dress 2, Circle Top, and Circle Dress were produced in One-Size. The resulting garments were tested through a series of fittings, 'trying on' sessions and photo shoots with a professional photographer and finally modelled by 14 of the participants in a public dissemination event, held in April 2017, during Phase 3 of the project. The Emotional Fit salon was organised in association with Fashion Revolution Week to raise awareness of the older women's support for sustainable design (fig.7).
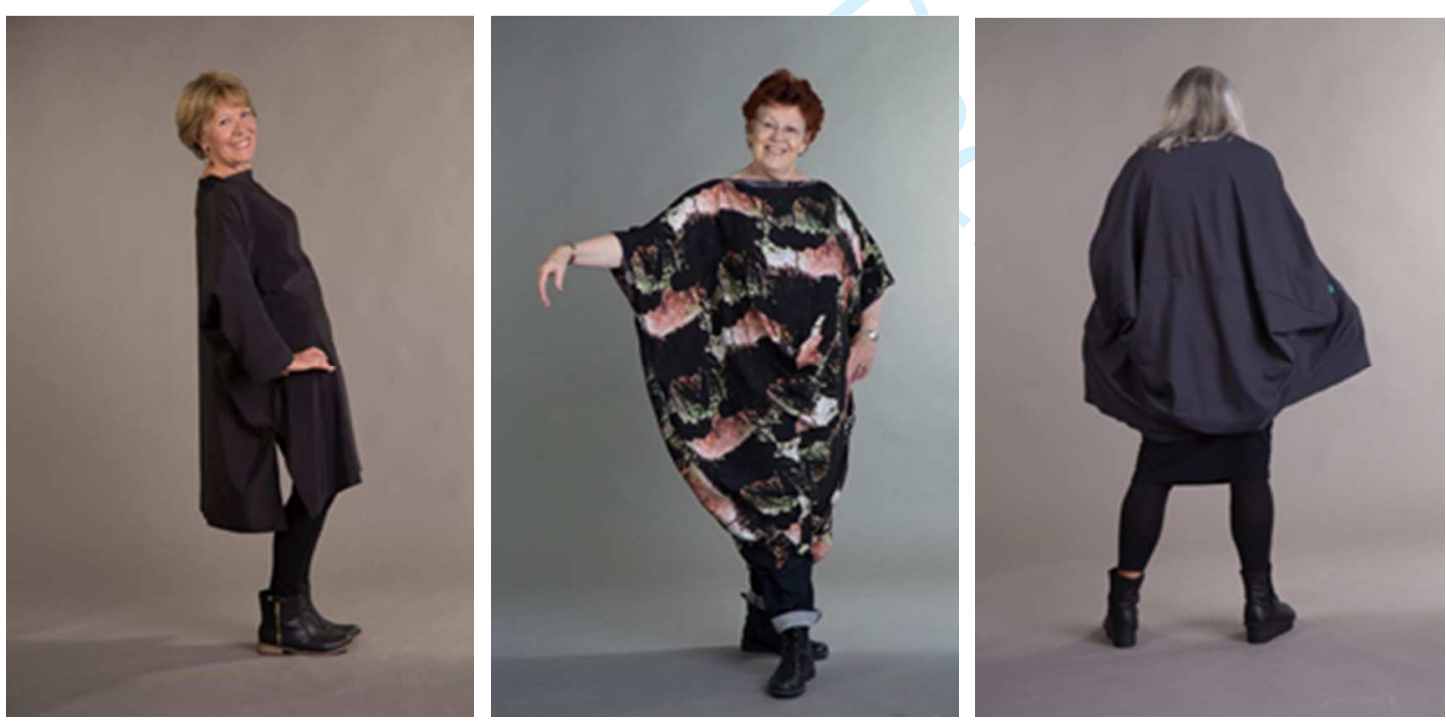

Figure 6. Rectangle Dress; Triangle Dress (Orchid) and Triangle Jacket (Photo by Rebecca Lewis) 


\section{Findings: Themes emerging from Phase Two}

Workshops 3 and 4 were crucial in determining textile and shape selection for garment prototypes, produced to visualise, test and disseminate the research. The co-designing process involved potential customers mapping their design preferences into the material domain of a garment (Fiore et al., 2001). Feedback on aesthetics found that while some prints were universal in their appeal, others were preferred as panels or linings to augment personalization in line with an "artisanal approach" (Aakko 2016). Generally, large-scale patterns were preferred over small repeats, pockets were essential and ties and drawstrings allowing for multiple styling options were popular. The key findings from Workshops 3 and 4 revolved around the importance of facilitating the conditions for empirical research by providing the opportunity for all stakeholders to explore their natural and professional designing capabilities (Manzini 2015, p.37). Participants attending the Phase 2 workshops reported that it was only through active engagement in co-designing that they felt their specific needs and expectations were being considered. Furthermore, they reflected on how being involved in the inclusive and transparent process of publicly modelling the garments enhanced their sense of 'agency' (Goode 2016), allowing them to develop a more positive attitude towards themselves and the concept of fashion (Niinimaki and Koskiken, 2011).

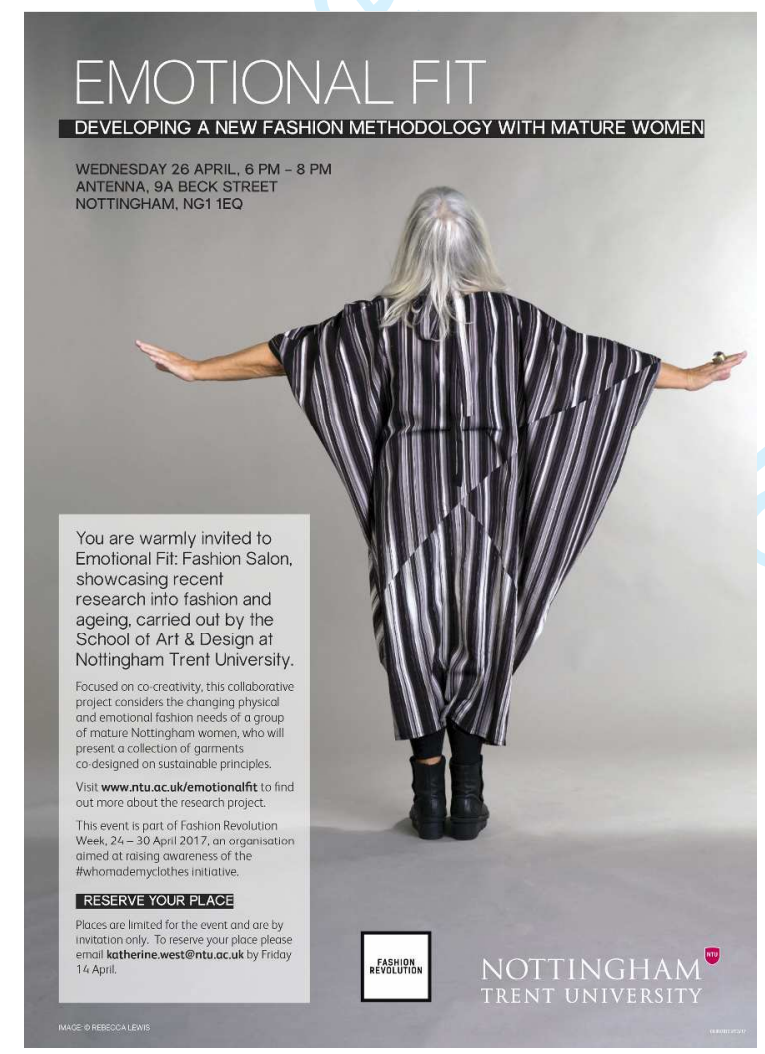

Figure 7. Triangle Dress (Stripe) on Emotional Fit: Fashion Salon advertisement (Photo by Rebecca Lewis) 


\section{Discussion}

While the designer's contribution to luxury businesses and clothing brands is relatively well studied, less well known are practice-based initiatives to the formulation of new business models. Through its focus on collaborative design, the research contributes to the processes of value creation in a slow fashion business model.

The engagement of older consumers provides a methodology and practice-based approach to more successfully target niche production consistent with SME fashion businesses. Based on these considerations and with the aim of fitting multiple sizes within a single garment silhouette (e.g. 8-12: Small; 12-16: Medium; 16-20: Ample) a series of prototypes were created by applying zero and minimalwaste design principles (Rissanen and McQuillan, 2015: Townsend and Mills, 2013). By working between bespoke blocks, the dress stand and designing round the figure (Aldrich 2004: 4) styles were developed to accommodate a range of different body shapes within a single style. Furthermore, the use of geometric, draped volumes facilitated the integration of garment details and engineered digital prints (Townsend in Aldrich 2004: 189) to facilitate personalization and extend the typical lifecycle of a fashionable garment. The decision to use enveloping shapes was primarily informed by the physiological changes experienced by the sample of women and their implications for apparel design (Bryson, 2014). The strong desire of the women to be able to convey their individuality and agency (Goode, 2016) was mediated through transformable design features, which allow the wearer to customize and manipulate the fit and length of specific garments. The design of printed textiles augmented these styles, introducing variation in terms of colour, pattern and the potential to visually contour the form via optical and camouflage-style imagery (Townsend, 2004).

The co-design phases of the action research (fig. 8) build upon independent fashion design business models (Aakko 2016; Atacac 2016, Minney, 2016) by incorporating local knowledge of customer preferences (Fletcher and Grose, 2012). Moreover, the value acquired from the aesthetic and measurement data to inform styling, shaping and sizing criteria, supports a 'bespoke group' fashion business model that can be applied to SME businesses. The findings demonstrate how consumers have the opportunity to personalize their garments, by selecting from the following:

- A range of different garment silhouettes based on geometrics

- Styles incorporating garment details that facilitate personalization

- Flexible sizing ranges to holistically accommodate different body shapes

- A selection of different fabric qualities and colourways to choose from

- Contrasting print styles and structures to choose from 


\section{Phase One: Gathering experiential knowledge and design data}

\begin{tabular}{|c|c|}
\hline $\begin{array}{l}\text { Methods: } \\
\text { 1. creative workshops with the participants } \\
\text { (co-designers) } \\
\text { 2. in-depth interviews } \\
\text { 3. personal inventories }\end{array}$ & $\begin{array}{l}\text { Outcomes: } \\
\text { 1. a series of calico bodices (produced to the } \\
\text { participants' individual measurements and } \\
\text { according to UK British Standard sizing charts) } \\
\text { 2. a series of simple geometric shapes } \\
\text { coordinated with selected print swatches }\end{array}$ \\
\hline Phase Two: Knowledge ex & d testing potential solutions \\
\hline $\begin{array}{l}\text { Methods: } \\
\text { 1. creative workshops with the participants } \\
\text { (co-designers) } \\
\text { 2. personal inventories }\end{array}$ & $\begin{array}{l}\text { Outcomes: } \\
\text { 1. a series of fully resolved toiles including: } \\
\text { Triangle Dress, Triangle Tunic, Triangle Jacket, } \\
\text { Rectangle Dress, Circle Top, Circle Dress } \\
\text { (My Label/ Your Label/ Our Label/ Emotional Fit) }\end{array}$ \\
\hline \multicolumn{2}{|c|}{ Phase Three: Co-Designing with industry } \\
\hline $\begin{array}{l}\text { Proposed methods: } \\
\text { 1. a public forum (held in the UK) } \\
\text { 2. creative workshops with the participants (co- } \\
\text { designers), independent brands and retailers (UK } \\
\text { and New Zealand) }\end{array}$ & $\begin{array}{l}\text { Proposed outcomes: } \\
\text { 1. Emotional Fit garments - collaborative industry } \\
\text { production (distributed and sold via online and } \\
\text { offline channels) } \\
\text { 2. Online marketing forum }\end{array}$ \\
\hline
\end{tabular}

Figure 8. Phases of co-design in the slow business model

This alternative 'design approach' represents a strategy for mitigating the scale and nature of fashion consumption through 'localism', 'user involvement' (Fletcher, 2014) and 'artisanal' making practices (Aakko 2016). The research demonstrates the potential for creating new shared values by using action research and collaborative design practices to do 'things in a (radically) different way' (Manzini 2015, p.13). In addition to user engagement in the fashion designing process, the research demonstrates 
how value can be created through innovative design for 'long life' flexible garment solutions, based on sustainable design principles (Rissannen and McQuillan, 2016) combined with mass customization options (Gwilt and Rissanen, 2011, Twigger-Holroyd, 2010). The research provides new insights into the significance of emotional durability (Chapman 2015), to extend garment longevity through designers making deeper, more sustainable bonds with consumers through collaboration e.g. Our Label.

\section{Conclusion}

The research extends a resource-based approach to business model theory by explaining design as a value creating resource that responds to the particular ethical and sustainable needs of a target group of consumers (Teece 2010). In line with the core aim of the research, supported by daSilva and Trkman's (2014) generic framework, the design asset is enhanced by co-designing using external stakeholders consumers - and by engaging with the wider ecosystem, it develops the external sensing and generating phases of the business model (Chandrasekara and Harrison, 2013). The action research process strengthens the client-designer relationship, by enabling the consumers and designers to jointly understand the consumers' needs, and from the detailed analysis of each design stage, new prototype styles have emerged as the basis of a new product range. Through this engagement with consumers, the research responds to and Grimstad Klepp's (2015) call for clothing that is more carefully aligned with fit and style for longevity, but also to generate higher profits through increased sales and reduce promotional and clearance activity. In the context of management decision making, the research enables managers to decide on appropriate product range parameters based on enhanced knowledge of the mature female body shape and style aspirations.

A second research objective was to assess the applicability of participative action research to the development of a slow business model. The design work was informed by social research (Bryson 2015) to elicit understanding of the values informing emotional durability and longevity that are central to the slow fashion model. The project resulted in generalizable, rather than bespoke fashion principles that were informed by the recurring themes that emerged from the workshops and in-depth interviews. The methodology highlighted the need for new garment designs to evoke strong emotional attachment, while embracing aspects of sustainable and ethical production and consumption (Fletcher 2016).

The research further advanced understanding of the role of design in the fashion industry by contributing to a wider debate about the challenges of sustainability and designing for an ageing population. Far from 'fashion and age' not sitting well together (Twigg 2013) the research demonstrates the wealth of experience that mature women can contribute to the development of more open, sustainable 


\section{References}

Aakko, M. (2016) Fashion In-between: Artisanal design and production of fashion, $\mathrm{PhD}$ thesis, Aalto University, Helsinki, Finland.

Aldrich, W. (2004), Metric Pattern Cutting for Womenswear, $4^{\text {th }}$ Edition, Blackwell, Oxford.

Amit, R. and Zott, C. (2001), "Value creation in e-business", Strategic Management Journal, Vol.22

No.6-7, pp. 493-520.

Atacac (2016), Why We Do What We Do and How. Available at: http://atacac.com/company/ [Accessed $10 / 12 / 2016]$.

British Standard Institute (2001), BS En 13402-1:2001 Size Designation of Clothes. Terms, Definitions and Body Measurement Procedure, BSI, London.

Braungart, M., McDonough, W. and Bollinger, A. (2007), "Cradle-to-cradle design: creating healthy emissions - a strategy for eco-effective product and system design", Journal of Cleaner Production, Vol. 15 No. 13-14, pp. 1337-1348.

Bryman, A. (2016), Social Research Methods, 5th edn. Oxford University Press, Oxford.

Bryson, D. (2014), “Anatomical and physiological changes with age: implications for apparel design", in J. McCann and D. Bryson (eds.) Textile-led Design for the Active Ageing Population, Woodhead, London.

Casadesus-Masanell, R. and Ricart, J. E. (2010), "From strategy to business models and onto tactics". Long Range Planning, Vol.43, No.2-3, pp.195-215.

Cavalcante, S., Kesting, P. and Ulhøi, J. (2011), "Business model dynamics and innovation: (re)establishing the missing linkages", Management Decision, Vol.49 No.8, pp.1327-1342.

Chandrasekara, K. and Harrison, R. (2013), “A dynamic practice-based approach to Business Model construction in turbulent environments", in the Proceedings of the British Academy of Management conference, University of Liverpool, Liverpool.

Chapman, J. (2015), Emotionally Durable Design: Objects, Experiences, Empathy, Routledge, London. 
Chesbrough, H. (2010), "Business model innovation: opportunities and barriers", Long Range Planning, Vol. 43, pp. 354-363.

Child, J. Hsieh, L.Elbanna, S. Karmowska, J. Marinova, S. Puthusserry, P.Tsai, T. Narooz, R. Zhang, Y. (2017), "SME international business models: The role of context and experience", Journal of World Business, September, Vol.52 No.5, pp.664-679.

daSilva, C.M. and Trkman, P. (2014), "Business model: what it is and what it is not", Long Range Planning, Vol. 47, pp. 379-389.

da Silveira, G. J.C. (2011), "Our own translation box: Exploring proximity antecedents and performance implications of customer co-design in manufacturing", International Journal of Production Research, Vol. 49 No.13, pp. 3833-3854.

Durugbo, C. (2014), "Managing industrial service co-design: identifying challenges from technology firms", The Service Industries Journal, Vol. 34 No. 4, pp. 314-334.

Ertekin, Z.O.and Atik, D. (2015), "Sustainable Markets: Motivating Factors, Barriers, and Remedies for Mobilization of Slow Fashion", Journal of Macromarketing, Vol. 35 No.1, pp. 53-69.

Finlay, L. (2011), Phenomenology for Therapists: Researching the Lived World, Wiley-Blackwell, Oxford.

Fiore, A. M. Lee, S. Kunz, G. and Campbell, J.R. (2001), "Relationship between optimum stimulation level and willingness to use mass customization options", Journal of Fashion Marketing and Management, Vol. 5 No. 2, pp. 99-107.

Fletcher, Kate (2007), "Slow fashion”, Ecologist, (June 1), available at http:// www. theecologist.org / green_green_living/clothing/269245/slow_fashion.html, accessed November 29, 2012.

Fletcher, K. and Grose, L. (2012), Fashion and Sustainability: Design for Change, Laurence King, London.

Fletcher, K. (2014), Sustainable Fashion and Textiles: Design Journeys, 2nd edn., Routledge, Abingdon. Fletcher, K. (2016), Craft of Use: Post-Growth Fashion, Routledge: Abingdon.

Fogg, M. (2003), Boutique: A '60s Cultural Icon, Mitchell-Beazley, London.

Gilleard, C. and Higgs, P. (2014), Ageing, Corporeality and Embodiment, Anthem Press, London. Goode, J. (2016), "Fashioning the sixties: fashioning narratives of older women”, Ageing and Society, pp. $1-21$. 
Gwilt, A. and Rissanen, T. (2011), Shaping Sustainable Fashion: Changing the Way We Make and Use Clothes, Routledge, Abingdon.

Holmund, M., Hagman, A., and Polsa, P. (2011), “An exploration of how mature women buy clothing: empirical insight and a model", Journal of Fashion Marketing and Management, Vol.15 No.1, pp.108122.

Hurd Clarke, L., Griffin, M., and Maliha, K. (2009), "Bat wings, and turkey wattles: body transgressions and older women's strategic clothing choices”, Ageing and Society, Vol.29 No.5, pp.709-726.

Iltanen, S., and Topo, P. (2007), "Ethical implications of design practices. The case of industrially manufactured patient clothing in Finland", in the Proceedings of Design Inquiries - The Second Nordic Design Research Conference, $27^{\text {th }}-30^{\text {th }}$ May, Stockholm.

Ivankova, N. V. (2015) Mixed Methods Applications in Action Research, London: Sage.

Jin, B. Change, H.J. Matthews, D.R. and Gupta, M. (2012), "Fast fashion business model. What? Why and how? in T-M Choi (ed.) Fashion Supply Chain Management, Business Science Reference, Hershey PA pp.193-212.

Kent, A.M. (2017), "Personalisation and fashion design", in I. Kuksa and T. Fisher (eds.), Design for Personalisation, Routledge, Abingdon.

Laitala, K., Boks, C. and Grimstad Klepp, I. (2015), "Making clothing last: A design approach for reducing the environmental impacts", International Journal of Design, Vol. 9, No.2, pp. 93 -107. Langdridge, D. (2007), Phenomenological Psychology: Theory, Research and Method, Pearson, Harlow. Li, W.D., and Qiu, Z.M. (2006), 'State-of-the-art technologies and methodologies for collaborative product development systems', International Journal of Production Research, Vol.44 No.13, pp. 25252559.

Manzini, E. (2015), Design, When Everybody Designs - An Introduction to Design for Social Innovation, The MIT Press, Cambridge MA.

Markides, C. C. (2015), "Business models and modelling research on business models: challenges and opportunities", Advances in Strategic Management, Vol.33, pp.133-147.

Mateu, J.M. and March-Chorda, I. (2016), "Searching for better business models assessment methods". Management Decision, Vol.54 No.10, pp. 2433-2446.

McCann, J. (2008), "Design for ageing well: improving the quality of life for the ageing population using a technology enabled garment system”, Advances in Science and Technology, Vol.60, pp.154-163. 
McCann, J. (2016), “Sportswear design for the active ageing”, Fashion Practice, Vol. 8 No. 2, pp. 234256.

McCann, J. and Bryson, D. (eds.) (2014), Textile-led Design for the Active Ageing Population, Woodhead, Cambridge.

Mcgrath, H. and O'Toole, T. (2012) “Critical issues in research design in Action Research in an SME development context”, European Journal of Training and Development, Vol.36, No.2, p.508-526

Millspaugh, J.E. and Kent A.M. (2016), "Co-creation and the development of SME designer fashion enterprises", Journal of Fashion Marketing and Management, Vol. 30 No.3, pp. 322-338.

Minney, S. (2016), Slow Fashion: Aesthetics Meets Ethics, New Internationalist, London.

Mintel (2012), Fashion for the Over 55s. November, Mintel International, London.

Mintel (2015), Mature Beauty, December, Mintel International, London.

Mintel (2016), Womenswear, May, Mintel International, London.

Molderez, I. and Van Elst, B. (2015), "Barriers towards a systemic change in the clothing industry: How do sustainable fashion enterprises influence their sector", The Journal of Corporate Citizenship, Vol. 57, pp. 99-114.

Niinimaki, K. and Hassi, L. (2011) "Emerging Design Strategies in Sustainable Production and Consumption of Textiles and Clothing", Journal of Cleaner Production, Volume 19, Issue 16, pp. 18761883.

NOM*D (2016), About NOM*D, available at: https://www.nomdstore.com/us/?geoip [Accessed: 29/12/2016].

Pal, R. and Gander, J. (2018), “Modelling environmental value: An examination of sustainable business models within the fashion industry", Journal of Cleaner Production,Vol.184, pp. 251-263 Potishuk, V. (2013), “Defining the business model: where is the problem?”, in the Proceedings of the British Academy of Management Conference, University of Liverpool, Liverpool.

Peters, C. Shelton, A. and Thomas, J. (2011), "Self-concept and the fashion behavior of women over 50", Journal of Fashion Marketing and Management, Vol.15 No.3, pp. 291-305.

Piller, F. Schebert, P. Koch, M. and Moslein, K. (2005), "Overcoming mass confusion: collaborative customer co-design in online communities," Journal of Computer-Mediated Communication, Vol. 10, No. 4, available at: http://jcmc.indiana.edu/vol10/issue4/piller.html; accessed 24/09/2017. 
Reason, P. (1994), “Co-operative inquiry, participatory action research and action inquiry: three approaches to participative inquiry", in Denzin, N.K. and Lincoln, Y.S. (Eds), Handbook of Qualitative Research, Sage Publications, Thousand Oaks, CA, pp. 324-39.

Rissanen, T. and McQuillan, H. (2015), Zero Waste Fashion Design, Bloomsbury, London.

Roser,T. DeFillippi, R. and Goga Cooke, J. (2014), “Co-creation in design: how the UK company Own Label combines openness and ownership to manage talent”, Strategy and Leadership, Vol.42 No.5, pp.34-40.

Sadkowska, A., Townsend, K., Fisher, T. and Wilde, D. (2017) “(Dis-) Engaged older men? Hegemonic masculinity, fashion and ageing", Clothing Cultures, 4:3, pp.185-201.

Sanders, E.B.-N. and Stappers, P. J. (2008), "Co-creation and the new landscapes of design", CoDesign, Vol. 4, No. 1, pp.5-18.

Sanders, E. B.-N. and Stappers, P. J. (2012), Convivial Toolbox: Generative Research for the Front End of Design, BIS Publishers, Amsterdam.

Sheridan, M., Moore, C. and Nobbs, K. (2006), "Fast fashion requires fast marketing”, Journal of Fashion Marketing and Management, Vol.10 No.3, pp. 301-315.

Sissons, J. (2010), Basic Fashion Design 06: Knitwear, AVA, London.

Smith, J. A. (1996), "Beyond the divide between cognition and discourse: using interpretative phenomenological analysis in health psychology", Psychology and Health, Vol.11 No.2, pp.261- 271.

Smith, J. A., Flowers P. and Larkin, M. (2009), Interpretative Phenomenological Analysis: Theory, Method and Research, Sage, London.

Smithers, R. (2014), "New research claims the high street makes women over 50 feel ignored", The Guardian , $20^{\text {th }}$ November, available at: https://www.theguardian.com/fashion/fashionblog/2014/nov/20/new-research-claims-the-high-street-makes-women-over-50-feel-ignored, [Accessed: 20/02/2017].

Teece, D.J. (2010), “Business models, business strategy and innovation”, Long Range Planning, Vol.43 Nos. 2/3, pp.172-194.

Tiggemann, M., and Lacey, C. (2009), "Shopping for clothes: body satisfaction, appearance investment, and functions of clothing among female shoppers", Body Image, Vol. 6 No. 4, pp.285-291.

Townsend, K., (2004), “Transforming shape: hybrid practice as group activity”, The Design Journal, Vol. 7 No. 2, pp. 18-31. 
Townsend, K. and Mills, F. (2013), "Mastering Zero: How the pursuit of less waste leads to more creative pattern cutting", International Journal of Fashion Design, Technology and Education, Vol.6 No. 2, pp. 104-111.

Townsend, K., Sissons , J. and Sadkowska, A. (2017), "Emotional fit: developing a new fashion design methodology with mature women”, Clothing Cultures, 4:3. pp. 235-251.

Twigg, J. (2013), Fashion and Age: Dress, the Body and Later Life, Bloomsbury, London.

Twigger-Holroyd A. (2010), "Keep and share”, in J. Hemmings (Ed.) In The Loop: Knitting Now, Black Dog, London, pp. 132-139.

Ulrich, P. V. Anderson- Connell L. J. and Wu, W. (2003), "Consumer co-design of apparel for mass customization", Journal of Fashion Marketing and Management, Vol. 7 No. 4, pp. 398-412.

Wilkinson, S. (2003), "Focus groups", in J.A. Smith (Ed.), Qualitative Psychology: A Practical Guide to Methods, Sage, London.

Wu, J. (2010), “Co-design communities online: turning public creativity into wearable and sellable fashions", Fashion Practice, Vol. 2 No. 1, pp. 85-104. 